\title{
Transition pathways revisited: Established firms as multi-level actors in the heavy vehicle industry
}

\author{
Christian Berggren, Thomas Magnusson and Dedy Sushandoyo
}

\section{Linköping University Post Print}

\section{Tweet}

N.B.: When citing this work, cite the original article.

Original Publication:

Christian Berggren, Thomas Magnusson and Dedy Sushandoyo, Transition pathways revisited: Established firms as multi-level actors in the heavy vehicle industry, 2015, Research Policy, (44), 5, 1017-1028.

http://dx.doi.org/10.1016/j.respol.2014.11.009

Copyright: Elsevier http://www.elsevier.com/

Postprint available at: Linköping University Electronic Press

http://urn.kb.se/resolve?urn=urn:nbn:se:liu:diva-118235 


\title{
Transition pathways revisited: Established firms as multi-level actors in the heavy vehicle industry
}

Christian Berggren, corresponding author

Dept. of Management and Engineering, Linköping University, SE-581 83 Linköping, Sweden

Phone: +46 13 281500, Fax: +46 13 281873, Christian.Berggren@liu.se

Thomas Magnusson

Dept of Management and Engineering, Linköping University, SE-581 83 Linköping, Sweden

Thomas.Magnusson@liu.se

Dedy Sushandoyo

Dept of Management and Engineering, Linköping University, SE-581 83 Linköping, Sweden

\begin{abstract}
The multi-level perspective on sustainability transitions positions established firms (incumbents) as defenders of existing technologies at the "regime level". By contrast, it positions new entrants at the niche level, as promoters of new technologies. This paper challenges the positioning of firms as actors on either regime or niche levels. Based on a comparative analysis of technology strategies in the heavy vehicle industry, the paper shows that established firms are active at both levels, developing several technology alternatives simultaneously. This means that incumbents' technology strategies determine important parts of the required niche-regime interactions. The paper also shows how incumbents may pursue contrasting technology strategies. While some adopt a dualistic approach, keeping regime and niche level activities technologically and commercially separate, others develop integrated strategies where niche activities are leveraged to impact upon the regime level. The cases studied illustrate how the success of these integrated strategies depends on the emergence of bridging policies. Such policies are relevant both for linking early niche markets to broader regime-level markets, and for supporting the further technological advancements of niche markets.
\end{abstract}


In recent years, the multi-level perspective has emerged as one of the most influential contemporary theoretical frameworks for assessing and understanding sustainability transitions (Markard et al., 2012). The multi-level perspective identifies critical tensions between stabilising and destabilising forces involved in transition processes (Geels, 2002; Smith et al., 2010) and highlights the importance of creating linkages between different levels, especially between the so-called regime and niche levels (Geels and Schot, 2007; Smith, 2007; Jørgensen, 2012). Scholars adopting the multi-level perspective describe the regime as an institutionalised, persistent, path-dependent, and rigid structure that favours stability and allows only incremental advancement (Fuenfschilling and Truffer, 2014). In contrast, they describe niches as local and dynamic 'protective spaces' (Smith and Raven, 2012) that facilitate the development and introduction of alternative technologies, making it possible for them to gain acceptance in the society (Schot et al., 1994; Kemp et al., 1998; Hoogma et al., 2002; Schot and Geels, 2008).

In a short time, this framework has inspired a rich literature, with a particular interest in transitions towards more sustainable patterns of production and consumption. In most cases, research attention has been directed at sectors such as energy and transport, which are associated with significant environmental impacts and involve complex capital goods. With a few exceptions, the framework has been built on geographically demarcated studies, and a majority of these studies have a national focus. There has been much less emphasis on organisational actors. As noted by Markard et al. (2012), the multi-level perspective suffers from a lack of analysis of the strategies of firms and their importance in transitions.

Merging the multi-level perspective with the literature on technology strategy, this paper will focus on the role of established firms in sustainability transitions. The paper examines an extended innovation process in a complex capital goods industry, the heavy vehicle sector, and presents detailed comparative case studies of the development and commercialisation of heavy hybrid-electric powertrains. The case analysis shows that established firms may pursue markedly different technology strategies with crucial consequences for transition prospects; further, these strategies can be much more ambitious than previously hypothesized in descriptions of transition pathways (Geels and Schot, 2007). The analysis highlights the innovative capacity of incumbent firms (cf. Schumpeter, 1942/2010), underlining that while niches are important for transitions, they are simultaneously problematic since they have a tendency to fragmentation and present difficulties in expanding beyond narrow boundaries. 
This implies that transitions in complex capital goods industries require bridging policies that interact with the relevant strategies of firms to achieve the critical diffusion of sustainable technologies to broader segments and volume markets.

The remainder of the paper is organised as follows. A brief review of the extant literature on transition pathways and technology strategy precedes a section on the industry context, and another on the research design. The subsequent section presents the hybrid-electric development efforts at two leading heavy vehicle manufacturers during the period 2005-2010, and discusses why one of them cancelled this effort. A comparison of the leading industry competitors in the early commercialisation phase in 2010-2012 follows. The final sections analyse the industrial and theoretical implications, and highlight critical factors for challenging an entrenched regime.

\section{Theoretical framework}

\subsection{Transition pathways and regime-niche interaction}

Multi-level theorists define transitions as "major, long-term technological changes in the way societal functions are fulfilled' (Geels, 2002: 1257). The multi-level perspective offers a framework that makes it possible to map such change processes. The distinction between regimes and niches is central in this framework. The regime is depicted as a highly structured entity that associates technologies with societal practices. In addition to technologies, the regime incorporates related scientific knowledge bases, markets, user preferences, industry structures, policies, and cultural habits (Geels, 2004). Hence, the concept of the regime emphasises that technology is deeply embedded in social and institutional structures. The regime is 'dynamically stable' (Geels and Kemp, 2007), implying that it can accommodate incremental innovations along established trajectories; however, it has problems in driving radical technological innovation.

Radical innovations emerge in niches (Geels, 2002). According to the multi-level perspective, regimes and niches 'are similar kinds of structures, although different in size and stability' (Geels and Schot, 2007: 402). Whereas regimes are large, stable, and highly structured entities, niches are small, dynamic, and characterised by a low level of structuration. The literature on strategic niche management elaborates the concept of niches further, making distinctions between technological niches and market niches (Schot and Geels, 2008). Technological niches 
refer to local field tests and demonstrations involving a number of relevant stakeholders, including manufacturing firms, users, and policy makers. The construction of such niches, which align technological artefacts with societal expectations and institutional frameworks, makes it possible to build social acceptance for new technology in a controlled manner before a broader market introduction. In this context, market niches refer to limited geographical areas or narrow domains of application in which the particular merits of the new technology are of great value, while the deficiencies are less problematic. Hence, they provide favourable selection environments and favour further development and refinement. When the new technology is eventually launched on mainstream markets, these niches would have played a significant role in the preceding progress (Rip, 1995). Summarising the importance of technological and market niches for transition processes, Smith and Raven (2012) argue that these niches jointly provide protective spaces that nurture interactive learning processes and shield new technologies from premature competitive pressures. Moreover, by attracting support for new technology, they provide critical empowerment by either making the innovations competitive within the unchanged selection environments or contributing to changes in the mainstream selection environments.

Responding to criticism that the original multi-level perspective presented very weak conceptualisations of agency and that transition theories need to pay more attention to regimeniche translations and interactions (Smith et al., 2005; Smith, 2007), Geels and Schot (2007) suggest a typology of four transition pathways based on the main actors involved:

1. Transformation: The regime actors adjust established technologies and practices in response to external pressure.

2. Technological substitution: The incumbent firms promoting regime technologies compete with the new firms promoting alternative technologies.

3. Reconfiguration: The regime actors adopt component innovations developed by the new suppliers. The new suppliers compete with the established suppliers.

4. De-alignment and re-alignment: The regime completely loses its legitimacy, and competition ensues among the new niche actors promoting various alternative technologies.

Of these four pathways, technological substitution and reconfiguration describe different kinds of regime-niche interactions. In the case of technological substitution, the existing technology is eventually replaced by new technology through a process of 'niche accumulation' (Geels and 
Schot, 2007: 410), in which the new technology promoted by the niche actors captures larger segments of the market. This pathway describes the tensions, power struggles, and fierce competition between niches and regimes. The competition constitutes a forceful process that eventually leads to the demise of established firms.

Reconfiguration, on the other hand, describes a pathway in which the incumbent (regime-level) actors adopt multiple new component technologies introduced by the new suppliers (the nichelevel actors). This pathway is particularly relevant for complex systems that are based on several interacting technologies. It suggests a symbiotic relationship between the niche- and regime-level actors. While the industry incumbents continue to prosper, competition ensues between the new and the established component suppliers.

Although the typology suggested by Geels and Schot (2007) covers a spectrum of different trajectories, the incumbents ('regime actors') are essentially depicted as either defending and adjusting their entrenched technologies or picking up innovations developed by the new supplier firms. Their perception of industrial firms seems to be inspired by 'Schumpeter I', in which new firms are the agents of new ideas and innovations (Schumpeter, 1911/2008), and established firms resist change (cf. Wells and Nieuwenhuis, 2012). However, this perception offers a limited understanding of the technological activities and strategies that incumbent firms may pursue in eras of ferment (Anderson and Tushman, 1990), when incremental improvements along an established trajectory are replaced by experimentation and competition involving different technologies. In such periods, several interrelated strategic dimensions are open to established firms - from the selection of appropriate new technologies, to the scope of their development and application, and the sourcing of the requisite knowledge and resources. These core dimensions of a firm's technology strategy will be investigated further in this paper.

\subsection{Technology strategy}

The first strategic dimension involves the selection of promising technologies and the development of these technologies into new competitive products (Helfat and Raubitschek, 2000). A key aspect in complex product industries concerns the choice of product architecture, specifically the level of modularity versus integrality (Zirpoli and Becker, 2011). Modularity, i.e. architecture with standardised interfaces and interchangeable components (Mikkola, 2003), supposedly results in flexibility for the producing firms and makes it possible to reap benefits of scale through the extensive use of external suppliers. New component technologies are easily 
adopted by the manufacturers as long as the interfaces remain stable. In contrast, integral product architectures imply that the manufacturing firms have to manage both deep componentrelated knowledge as well as broad system-related architectural knowledge (Becker and Zirpoli, 2003;Brusoni et al., 2001; Takeishi, 2002). Here, discontinuous technological changes bring in the additional challenge of balancing existing and new knowledge at both levels, while the integration requirements restrict the possibilities for separation and outsourcing. Therefore, firms developing new integral architectures in these industries need sustained efforts in dynamic integration (Bergek et al., 2013).

The second dimension involves the scope of the technological effort. In the context of this paper, scope refers to product focus versus technology platforms, where the platforms are designed to be applicable to products across different market segments, which allows the creation of derivatives through the addition, substitution, or removal of features (Wheelwright and Clark, 1992). The third strategy dimension involves sourcing the new technologies. The firms need to decide how much technology should be developed internally, and what, where, and how to source technology externally, through licensing or in some other way (Maidique and Patch, 1982; Zahra et al., 1994; Bergek et al., 2009). In the studied context, licensing has not been an option; the key issues have been to first decide the level of in-house development versus external sourcing and to subsequently identify and groom capable new suppliers, which included effective ways of joint development.

Technology strategies are related to strategies for market exploitation and commercialisation (Zahra et al., 1999). Prior studies have reported the problems posed by early entry and the burnout of pioneers (cf. Olleros, 1986) and have showed that the so-called 'first-mover advantage' is often the result of a selection bias and should be interpreted as 'first survivor advantage' (Vidal and Mitchell, 2013). Studies of several major technological innovations in capital goods industries have identified the difficulties for an innovation to become accepted when there is only one manufacturer promoting the new technology. Even if early users validate the superiority of the new technology, professional customers seem reluctant to take the innovation on board, lest they become captive to the single supplier (Berggren, 2004).

Studies of innovations in consumer products have shown how firms often introduce new devices at a premium price in high-end markets, and subsequently ramp up the production scale and lower the price to reach the mass markets (Moore, 1999; Suarez, 2004). Professional markets for capital goods are different. Many different segments with diverse application contexts may exist for the same product type. Therefore, manufacturers can seldom rank the 
market segments in a hierarchy from high-end to low-end within a given region, such as North America (NA) or the European Union (EU). This makes it hard to identify the customer groups that are prepared to pay premium prices when volumes are still low and the outcome is uncertain.

Strategic niche management theories emphasise the role of policy-induced proto markets in protecting and supporting the early commercialisation of such pioneering technologies before they can compete in mainstream markets (Kemp et al., 1998). These studies highlight the importance for firms to engage with social and political actors (Smith and Raven, 2012), which resonates with a central finding in the extant literature on industry dynamics: that technical superiority by itself is not enough to establish the dominance of a new technology (Anderson and Tushman, 1990; Lee et al., 1995). While theories of strategic niche management (Schot et al., 1994; Kemp et al., 1998; Hoogma et al., 2002; Schot and Geels, 2008) tend to emphasise competition between technologies (cf. Arthur, 1989; Cowan, 1990; Cowan and Gunby, 1996; Menanteau and Lefebvre, 2000; De Liso and Filatrella, 2008), these theories show less interest in the competition between firms. Moreover, while niches are critical for the introduction of innovative products, 'a large gap frequently exists between the price/performance requirements of these nursing markets and the requirements of a mass market' (Andersson and Jacobsson, 2000: 1039), which is particularly evident in capital-intensive, complex product industries. This point highlights the need for bridging policies that can promote further market development and diffusion (Sushandoyo and Magnusson, 2014). We will return to this issue after presenting the analysis of the cases, which form the empirical heart of the paper. To understand these cases, the next section will first provide a background to the relevant industry context.

\section{Background: The heavy vehicle industry in an 'era of ferment'}

The automotive industry figures prominently in both classic studies on innovation as well as recent innovation studies (Abernathy, 1978; Dijk and Yarime, 2010; Magnusson and Berggren, 2011; Offer et al., 2010; Sierzchula et al., 2012; Wesseling et al., 2013). Almost all of this research, however, has concentrated on passenger cars, in the US context in particular. Since heavy vehicles have been much less studied, some important aspects of this sector are presented in this section, especially regarding the urban bus segment, which is currently at the innovation frontier. The heavy vehicle sector comprises several different types of products, such as trucks, 
buses, construction equipment, and military vehicles, all of which use similar powertrain components. In terms of volume, heavy trucks constitute the leading product category.

Annually, about 1 million heavy vehicles are produced in the combined region of NA and the EU (average figures for the period 2010-2012). While this volume is significant, it is much lower than the number of cars (including sports/suburban utility vehicles) produced in the same region, which totals about 30 million annually. This means that economies of scale are more difficult to achieve in the heavy vehicle segment than in the other automobile sectors. In the heavy vehicle segment, component suppliers operate at a lower scale, R\&D projects need to be amortised over longer periods of time, and original equipment manufacturers (OEMs), i.e. the final product companies, need to carefully consider how to organise their product development internally and externally. Another difference between these sectors relates to the R\&D efforts required to comply with the regulations related to emissions. For gasoline cars, the major step in response to these regulations was the introduction of catalytic converters, forced by the amendments to the US Clean Air Act in the 1970-1990 period (Lee et al., 2010). For the actors in the heavy vehicle industry, the reduction of noxious emissions has been a considerably more difficult challenge. Regulation of these emissions started in the early 1990s, with significant increases in stringency over the last few years, such as the introduction of the Euro 6 emission standards in 2012-2014 and similar US standards for local pollutants: $\mathrm{CO}, \mathrm{NO}_{\mathrm{x}}$, and particulate matters. With these increases in stringency, which intended to make diesel engines as clean as gasoline engines, the emission standards in Europe and North America have become practically similar. While sophisticated engine controls, high-pressure injection systems, and expensive after-treatment devices all contribute to improved environmental performance; they simultaneously increase costs considerably. For instance, Scania, one of the leading heavy truck manufacturers, spent in excess of 1 billion euros to develop engines compatible with the Euro 6 standards (Scania, 2011). The convergence in global regulations has accelerated the process whereby European firms operate in North America, and US firms (OEMs and suppliers) operate in Europe. However, trucks and buses from emerging economies such as China (the biggest global producer of heavy vehicles) adhere to lower standards and are not present in the North American or European markets.

Even though the emissions standards and technologies for heavy vehicles are relatively similar in Europe and North America, the industrial organisation in these regions differs markedly. In Europe, OEMs such as Daimler, IVECO, MAN, Scania, and Volvo offer integrated products with internally modularised designs. In contrast, US truck companies assemble only the final 
product; they source key components such as engines, axles, and gearboxes from external specialists according to the customer specifications. European firms operating in the US have sought to replace this disintegrated industrial structure with their own integrated products; however, diffusion has been slow.

Since the end of WWII, diesel engines have been the dominant powertrain technology in both these regions and in all heavy vehicle segments. In terms of volume, city buses are a small segment, with 25,000 buses produced per year in the combined NA and EU region. However, this segment plays a much more important role in terms of technological development than what is conveyed by the production numbers, as is pointed out in an industry report:

The transit (public transport) bus industry has played a crucial role in proving and adopting advanced vehicle technologies. Transit fleets have the advantage of large-scale refueling and centralized management of vehicles, which facilitates the testing and refining of new technologies. The examples of $\mathrm{CNG}$, plug-in hybrid and all-electric buses show how transit buses are well suited to preparing the way for other motor vehicles in new technology application. (Lowe et al., 2009: 22)

With high stress impact, frequent starts and stops, and very little steady operation on the road, the urban bus segment offers a particularly demanding market for testing and validating new engine types. In the US, these challenges have led to a remarkable consolidation in the market, leaving Cummins as the only engine supplier for the domestic industry. In contrast, all the major heavy truck makers in Europe have adapted their diesel engines to the city bus segment. In addition to producing complete buses, they also supply chassis and powertrains to independent bus builders. For example, in the UK, Volvo Bus collaborates with the bus builder Wrightbus. City bus operators tend to use their buses for significant periods, sometimes for the entire lifespan of the vehicle, i.e. 10-15 years; this presents a clear advantage from the perspective of testing new technologies. In contrast, distribution trucks are used for only 2-4 years before the operators sell them to other firms; this makes the payoff time for fuel-saving devices much shorter (KPMG, 2011). In the US as well as the EU, municipal authorities who frequently adopt local regulations to cut emissions beyond national standards in favour of specific new technologies, influence the city bus market. This creates opportunities for manufacturers to test new powertrain concepts in small-scale projects and opens up the market for specialised bus builders who source their powertrains externally; however, it simultaneously contributes to a fragmentation of the industry. In the US, this fragmentation is exacerbated by rules forcing municipalities to buy only American-made products. 
After a long period of technological stability and incremental improvements in heavy vehicle powertrains, the industry is currently facing an era of ferment, particularly in the city/transit bus sub-segment. This discontinuity is due to a combination of factors: long-term increase in fuel costs and concerns regarding future availability of fuel; continuous escalation in regulatory stringencies, where the standards on local pollution are expected to be accompanied by regulations of $\mathrm{CO}_{2}$ emissions as well; and a rapidly expanding repertoire of technological solutions. This has created a deep sense of uncertainty within the industry:

We used to have a clear technological focus: Diesel. Now there is a huge diversification, related to energy management, electric devices, hybrid technologies, materials, etc. but at the same time, it is hard to compete with diesel fuel in terms of energy density. A key problem is what to choose and how to calculate the real benefits. (Vice President R\&D, Scania, 2013)

In the urban bus segment, aspects related to the image and quality of public transport, as well as demands for smoother and more comfortable vehicles with reduced vibrations and noise, reinforce the search for new solutions. Powertrains that were pioneered in the car industry such as hybrid-electric, plug-in electric, and purely electric vehicles - increase the public pressure for change. The first and technologically simplest response of heavy bus makers has been to replace oil with other fuels such as ethanol or compressed natural gas (CNG); the latter is the main alternative to diesel globally (Lowe et al., 2009). These options require only minor modifications of the main powertrain design. While they add alternative fuel sources and reduce some local pollutants, these benefits come at the expense of reduced overall energy efficiency. A technologically more demanding response involves the development of new powertrain architectures. While prototypes of fuel cell-powered buses have been tested in various European cities since the 1990s, these vehicles have never entered commercial production due to their prohibitive costs: 1 million pounds compared to 200000 pounds for a conventional diesel bus (TfL, 2012a). A comprehensive study of different technologies by Transport for London (TfL) found hybrid-electric powertrains to be the most promising alternative in terms of environmental performance, readiness to market, cost, and usability (TfL, 2012a). In urban traffic, this technology has the potential to reduce fuel consumption and overall emissions by $25 \%$ or more (depending on driving conditions) and to increase passenger comfort by means of smoother acceleration and reduced noise. Further, hybrid-electric powertrains can be upgraded to plug-in status, offering silent and zero-emission electric drives on inner-city routes. For operators as well as manufacturers, hybrid-electric powertrains offer an attractive bridging 
technology in the medium term (FCHJU, 2012: 10). Starting in 2004 (the first year of significant sales), hybrid-electric buses emerged as a green option in the US (Lowe et al., 2009). A few years later, they began to diffuse in Europe, encouraged by a public competitive technology trial organised by TfL.

\section{Research design: Two longitudinal, comparative case studies}

This paper builds on two comparative studies - two 'path-way cases' (Gerring, 2008). The first case study investigates the efforts of two Swedish firms, Volvo and Scania, to develop heavy hybrid-electric powertrains in time for the London Olympics (2012). Sölvell et al. (1991) note the competitive strength of the Swedish heavy vehicle sector; the selected firms belong to the industry's global leaders. At the outset, the two firms pursued starkly different technology strategies, which both seemed to be supported by clear business cases. The study shows why Scania eventually cancelled its separate powertrain project for buses, whereas Volvo prevailed and launched the first European heavy city bus powered by a parallel hybrid powertrain in 2010 . The second case study investigates the early commercialisation phase of hybrid-electric powertrains, comparing the integrated hybrid powertrain from Volvo with the differently configured powertrain supplied by a division of BAE Systems (a multinational defence industry conglomerate) in collaboration with local bus builders. These two configurations were the leading contenders in the hybrid bus trial organised by TfL.

While the first study analyses the technology strategies of two OEMs, the second study relates the technology strategies of two firms to their different market strategies. Thus, these studies complement each other to build a deeper understanding of the key issues involved in the early transition process of a complex goods industry. See Table 1 for an overview of the two studies.

\section{(Insert Table 1 around here)}

Study 1 builds on interviews conducted during the project execution phase with R\&D engineers, project managers, and executives at Scania and Volvo Powertrain and with R\&D managers at key suppliers such as Voith (the supplier of electric propulsion and hybrid control systems to Scania) and Kollmorgen (the machine supplier to Volvo), as well as published technical reports and participation in industry conferences. Study 2 builds on interviews with key managers at 
TfL and with UK bus operators (Arriva, Go Ahead, Stagecoach, and First Group). This is complemented by interviews within Volvo, Volvo UK, and BAE Systems (and its partner ADL), interviews with researchers, and secondary sources (such as customer surveys commissioned by TfL). For a list of interviewees, see Appendix A.

\section{Two technology strategies}

\subsection{Technology choices: Two competing powertrain architectures}

In hybrid-electric powertrains, the diesel engine is connected to several new components such as one or several electric motors/generators, an energy storage device, power electronics, and a hybrid management system. At the system level, this combination of new components and interfaces amounts to discontinuous innovation (cf. Iansiti, 1995; Veryzer, 1998). The application of existing but evolving components and completely new devices requires the interaction of different disciplines and knowledge bases, such as combustion, electrotechnical, electronic, software, and chemical engineering. Several hybrid powertrain architectures exist; the principal two alternatives are series and parallel hybrid powertrains. The choice of either of them has vast implications.

In a series hybrid powertrain, the diesel engine is coupled to a generator producing electric power, which is used to feed the motor(s) propelling the wheels. An energy storage device absorbs excess power from the engine or from the braking mechanism. This configuration, involving a powerful generator and motor, maximises the absorption and use of braking energy in intense stop-and-go traffic. Ideally, the diesel engine would run at optimal speed; however, in real traffic conditions, the engine performance depends on how effectively the hybrid control system combines the various energy sources. A significant disadvantage is the high product cost of the three full-scale machines (engine, generator, motor). Moreover, due to the several power conversions involved (from motive power to electric power and back to motive power), the efficiency is low outside inner-city routes where less braking energy can be recovered. From a development and sourcing perspective, an advantage is the modular character of the series hybrid powertrain - an independent source may supply the generator/motor package (with or without energy storage).

In a parallel hybrid powertrain, an electric motor assists a downsized diesel engine when the vehicle needs extra power. The electric motor can also be used to take off from standstill. The engine and motor are directly connected to a computerised transmission that propels the wheels 
via a differential. Similar to the series hybrid, an energy storage device absorbs and releases excess power from the engine or from the braking mechanism. In contrast to the series hybrid, no separate generator is required in a parallel hybrid powertrain (Guzzella and Sciaretta, 2005). While this design offers lower product cost, considerably more development efforts are required to accomplish the high level of integration that is needed. Further, the configuration does not support any modular strategy. Toyota Prius represents a variant of this configuration in the car industry.

In the comparative cases discussed in this section, these two types of hybrid powertrains constitute a key element of the competition, with implications for R\&D organisation, development, product costs, and cross-segment synergies. City bus applications currently offer the freedom of choice between these configurations depending on how bus operators evaluate different aspects. In these applications, both types of hybrids can achieve a significant reduction in fuel consumption (25-35\% or more). Outside dense urban areas, the series hybrid is less useful; and for intercity coaches that drive longer distances with few possibilities to recover braking energy, parallel hybrids are definitely more efficient. The relative reduction in fuel consumption is lower than in inner city traffic; however, since these coaches cover longer distances, the total fuel savings could be considerable.

For Europe's integrated manufacturers, the possibilities of synergies between bus and truck applications are an important aspect. In dense urban areas, where trucks operate with a considerable amount of stop-and-go driving, series as well as parallel hybrids are theoretically feasible; however, parallel configurations outperform the series hybrids as soon as they leave the city centres. Long-haulage trucks for the transport of goods or bulk liquids between distant destinations at cruising speed constitute the main segment of Volvo as well as Scania. While cost-effective, mass-produced hybrid solutions constitute an interesting opportunity, the only possible powertrain architecture is the parallel type.

\subsection{Hybrid development at Scania: A strategy of separation}

Scania, a focused manufacturer of heavy trucks and buses, is among the global top ten producers of heavy vehicles, with an annual truck production ranging between 59,000 and 66,000 units in the period 2008-2010. Over decades, the company has fine-tuned an internally standardised design approach, where a limited number of subsystems (engines, gearboxes, axles, cabins, etc.) and the components within these systems are configured into an almost endless variety of final products according to customer specifications. This design philosophy 
is supported by a strategy of organic growth and a commitment to product development through a process of 'Continuous Evolution of Properties Planned in Small Steps' (Scania, 2004). Incremental improvement of the diesel engine occupies a place of pride: 'The powertrain is of central importance, greatly affecting a vehicle's character and performance. It also provides the basis for fuel economy, environmental characteristics and the long service life of Scania's products (Scania, 2007: 26).

\subsubsection{A series hybrid targeted for the city bus market}

The technological competition to develop hybrid-electric powertrains strongly challenged Scania's strategy of improvements in small steps. Starting in the 1980s, Scania conducted smallscale research and development in hybrid technology, testing several different types of new powertrains, including fuel cells (Folkesson, 2008). In 2004, Scania began a focussed project with the intention of building a full-scale demonstration version of a hybrid bus, which was a very unusual step for the company. The overall goal of the project was 'to raise the image of urban buses and to make the bus more attractive for all parties concerned: passengers, drivers, operators and society' (Overgaard and Folkessson, 2007: 4). Series hybrid architecture was chosen for the prototype based on the assumption that this would offer unique advantages in inner-city applications, such as high capacity to absorb braking energy and the unprecedented freedom to optimise the bus interiors for rapid passenger flows without the restrictions caused by the mechanical connection between the engine and the wheels in conventional buses. After the successful presentation of the prototype in 2007 at the International Association of Public Transport, Scania's top management decided to release the prototype for detailed engineering aimed at a commercial launch, hopefully in time for the London Olympics in 2012. A key milestone was an extended field test and demonstration in Stockholm around 2008-2009. With the decision to go for market introduction, much more interaction was required with specialists with regard to the conventional components needed for a complete bus; however, the project retained its autonomous status and its limited scope.

Being a project with a limited application constrained the company's possibilities to develop deep in-house knowledge in hybrid-related areas. The project selected unconventional technologies and new suppliers for key components, and outsourced substantial portions of the development. For energy storage, the project opted for super capacitors - an electrostatic device with too low energy density to enable electric drive, but with high power density suited to city applications where the recovery of braking energy is key (Folkesson, 2008). The project 
configured a standard 9-litre diesel engine with a high torque generator and a new type of electrical propulsion motor of trans flux type. A new supplier, Voith Turbo in Germany, was responsible for developing and delivering the generator and propulsion motor, as well as the hybrid drive module. This division of labour limited Scania's need to invest in new knowledge areas; however, this restricted its insights in specific technical solutions and reduced the possibility to optimise the new powertrain as a whole.

\subsubsection{Dual development: Different technologies for trucks and buses}

Several years after the bus pilot project began; Scania initiated the development of a hybrid powertrain for its trucks. For this project, the company opted for a parallel architecture to suit the driving characteristics of its main truck segment. However, the series hybrid project continued its autonomous existence within the bus division. The two development efforts differed in several ways. The series hybrid project focused on developing the best solution for a specific niche, with a clear timetable and a near-term launch date. The parallel hybrid project was in line with Scania tradition and sought to develop a cost-effective solution that could be offered in all truck segments. The orientation was long term, and Scania did not specify any date for market launch.

During the financial crisis in 2008-2009, Scania's top management asked the R\&D division to re-evaluate its efforts. Although the series hybrid solution could offer superior convenience and an acceptable level of efficiency in specific urban conditions, Scania was unable to find any applications for the truck segments. When operating outside dense city traffic, the inherent losses in the series hybrid resulting from energy conversions (engine to generator, generator to electric motor) made this configuration $20 \%$ less efficient than a conventional diesel engine; therefore, the series hybrid was found to be not feasible, even for a garbage truck. The cost disadvantage of the series hybrid with its three full-scale machines was exacerbated by the disappointing cost curves for its key components, where Scania's choice differed from the main trends in the industry. These factors meant that a dedicated series hybrid bus would be a narrow and expensive niche product. Moreover, Scania was not able to establish close interactions with any niche customer in Stockholm, where the privatisation of public transport had reduced the previously integrated authority (Storstockholms Lokaltrafik - SL) to a purchasing body with very limited engineering resources and a focus on alternative fuels rather than alternative powertrains. All these factors resulted in a decision to cancel the series hybrid and to follow the technology route pioneered by the firm's Swedish 
competitor, Volvo; however, this decision was taken after a considerable time lag. In 2014, Scania finally launched a parallel hybrid bus to the market.

\subsection{Hybrid development at the Volvo Group: A strategy for integration}

The Volvo Group competes with Daimler for the top position in global truck production; it is also a significant actor in heavy buses and construction equipment. Growing both organically as well as by international acquisitions, its truck production exceeds 200,000 annually; its total bus production is around $10 \%$ of this figure. During the period studied, two divisions - Volvo Technology and Volvo Powertrain - were responsible for R\&D, advanced engineering, and the development of engines and engine systems for the truck, bus, and construction equipment divisions. Because of its junior status, the bus division normally had to contend with derivatives developed from the components designed for trucks. The hybrid competition changed this priority in a dramatic way.

\subsubsection{Technology choice for a broad scope}

Experiments with hybrid-electric powertrains within the Volvo Group can be traced back to the mid-1980s; the company began engineering studies, developed demonstrators, and tested mechanical and hydraulic hybrids, series hybrids powered by gas turbines, and parallel electric hybrids. In contrast to the project at Scania, these early efforts and road tests involved a variety of applications including buses, trucks, and cars. ${ }^{1}$ In 2002, the company started an advanced engineering project involving a significant number of scientists and engineers to investigate which type of hybrid powertrain architecture would offer the best combination of fuel efficiency, robustness, and cost-effectiveness across segments. After a comprehensive analysis, Volvo's R\&D division decided to focus on developing a parallel hybrid. The first new powertrain prototypes were presented in 2005. The following year, the CEO announced Volvo's decision to commercially launch vehicles with hybrid powertrains in 2009, a unique event in the history of the Volvo Group.

This is the first time ever - nothing like that has happened before. It was surprising for everyone in the Volvo organization. We didn't even have a section [for hybrid development]. I think probably nothing would happen otherwise. ... It was a top-down decision at that time. (Manager of Business Packaging Team, VPT, interview in 2009)

\footnotetext{
${ }^{1}$ Until 1999, when Ford acquired Volvo's car division, the activities at the advanced engineering unit at Volvo Technology included R\&D related to both cars and heavy vehicles.
} 
Volvo's decision involved an investment of 200 million euros, plus support from the Swedish Energy Agency. The key challenges for Volvo's project concerned the scope of development and the sourcing of the new technologies. Previously, Volvo like other heavy vehicle manufacturers had offered modifications of their standard powertrains if customers demanded this and were prepared to pay the higher product cost. Such a strategy could be pursued as long as the adaptations involved very limited extra R\&D efforts. Volvo's integrated hybrid development was different since it necessitated a massive upfront R\&D investment. This investment required a much larger production volume than the city bus market could offer; thus, synergies with other product segments were a key consideration for Volvo.

Despite its scale disadvantage, the city bus niche constituted an ideal entry market. As was discussed in Section 3, firstly, the many hours of operation per day with tough driving cycles meant that the new technology could be tested thoroughly. Secondly, the regular routes involving many buses meant that the new powertrain could be rigorously compared to the conventional ones. Thirdly, daily maintenance at centralised depots meant that early defects could be spotted and corrected with a minimum of delay. Fourthly, bus customers with a longterm ownership commitment implied a much longer payoff time than the payoff times required by truck owners. Moreover, in metropolitan markets such as London, hybrid buses enjoyed the early support of Government programs.

At its public demonstration in 2006, Volvo presented prototypes of a hybrid bus as well as a hybrid truck. This platform strategy for the new powertrain continued with the explicit intention to obtain commonality across business segments. Thus, the powertrain project sought to design key components suitable for all of Volvo's vehicle categories. A 'business package team' played a key role as the interface between Volvo's powertrain development unit, the product divisions, and the suppliers; this team negotiated with the various parties to find common technologies and components that would fit all of Volvo's vehicles.

\subsubsection{Extensive investments in new knowledge}

Volvo's decision to focus on one integrated powertrain with a broad scope of vehicle applications helped the development project to gain momentum. Moreover, the development could enjoy synergies with the advances in conventional components, such as the company's recently launched computer-controlled gearbox (the I-shift). To safeguard seamless integration, the company decided to build in-house knowledge regarding several new 
components and subsystems. Thus, Volvo Powertrain invested in dedicated laboratories and personnel specialised in batteries (from cell chemistry to control strategies for battery systems), but also in engineering solutions for heavy-duty applications, including passive safety, vibrations, and thermal management. These knowledge investments were critical for effective collaboration with the new suppliers:

We have very good battery research team, and the best battery research equipment you can have. We have done very extensive data collection and testing, of all kinds of cells, in all kinds of arrays. So we have a huge amount of experience of different cells, and how they work and when we initiated a relationship with Magna as battery supplier we had a lot of people at Volvo specialized in the battery modeling and control. Magna of course also has that kind of knowledge. But we were very close to that and we were basically in this together. (Volvo's scientific advisor, interview in 2012)

Regarding control systems, another key component for efficient hybrid operation, Volvo decided to build internal knowledge and develop the major subsystems in-house, especially the hybrid control system. This system regulates the engagement and disengagement of electric and diesel power, gear-changing modes, and battery recharging, and thus controls the components and control units developed by the suppliers of the battery, motor drive, and power converter.

... The knowledge how to design, how to control, even at the detailed level, is inhouse knowledge. That doesn't mean we will produce machines. But we are putting our own software into the control; we know the details of it... In every moment, this software decides how much energy to take from the battery, how much to take from the diesel, how much to feed back to the battery... If you take a good solution and put it in the hand of two different companies, they will not have equally good vehicles, because the control systems may be different. If the control is inadequate, it doesn't help if the hardware is good. (Volvo's scientific advisor, interview in 2012)

In addition to internal R\&D investments, Volvo faced the challenge of selecting competent suppliers and persuading them to participate in the project and take it seriously. 
At that time, around 2005/2006, there were a lot of suppliers ready for the car business. Not so many were ready for heavy duty vehicles. There were a lot of suppliers telling us: 'you can buy two or three of our motors and put them in a series'. But we have the space constraint of the driveline. So it was; there were only a few. And we could not use components from the shelf. They needed to be absolutely tailor made for us. (Manager of Business Package Team, interview in 2009).

Volvo selected Magna Steyr as the supplier of battery systems. When their collaboration commenced, Magna was new in the energy storage business, and Volvo was its first customer for this type of battery. Based on in-house R\&D, Volvo could determine the detailed specifications of the battery, and the parties collaborated closely until the series production began. Volvo procured the electric motor for the hybrid powertrain from Kollmorgen. This company (a subsidiary of Danaher Motion, the world's largest supplier of electric motors for forklifts) was an entirely new supplier for Volvo. Unlike Scania, Volvo opted for a relatively mature technology - a radial flux permanent magnet synchronous motor (cf. Eriksson, 2007). Since Kollmorgen had never delivered electric motors for road vehicles before, Volvo needed to develop its own knowledge in high-voltage electrical engineering in order to specify its requirements related to robustness, safety, and manufacturability. A critical challenge for manufacturability as well as use in different vehicle applications was to keep the driveline tight and light, with the electric motor placed between the engine and the transmission, and the shaft of the electric motor connected tightly to the shafts of Volvo's components. As a result of this development project, Volvo could offer a compact parallel configuration featuring a smaller diesel engine (with 5-litre capacity compared to Scania's 9-litre engine), an electric motor packaged as an 'integrated starter alternator motor', a computer-controlled gearbox (I-shift), and lithium ion batteries on the roof as energy storage

\subsubsection{Market launch: Focus on hybrid buses}

After the public announcement in 2006, Volvo Powertrain accelerated the development of the new technology platform, and Volvo decided to focus on buses as the first application. The financial crisis in 2008-2009, which disproportionately hit the truck segment, reinforced this decision. Volvo Buses normally initiated development projects to satisfy customer requests or to meet regulatory requirements. In this case, there was no such input, which made it difficult 
for Volvo's product managers to estimate demand and justify the development project on a commercial basis. Thus, the top management's public announcement of its commitment to the project played a crucial role. In 2009, Volvo could begin small-scale deliveries of the new hybrid buses to customers in Europe; series production commenced the following year. To meet urban operational conditions, Volvo Buses set seven product targets, including attracting existing and new passengers, delivering maximum up-time and a high-quality drive experience, and achieving large volume production to make a short payback time possible (Volvo, 2007). After the successful development of the hybrid buses, it was now up to the market to test these targets.

\section{Competitive battles in an emerging niche}

\subsection{The London contest}

Like Scania, Volvo started the field tests of its new powertrain in its hometown, Gothenburg. However, the hybrid contest organised by Transport for London (TfL) quickly dwarfed these tests. FL's hybrid contest began in 2006 and gained momentum in 2009-2010. Within the EU, UK stands out as the leading bus market in terms of both volume as well as nationally coordinated incentives, such as the Green Bus program with 95 million pounds dedicated to the market introduction of new bus technologies in 2010-2012 (and further support after that year). London is the dominant market in the UK, with a fleet of 8,000 buses operating daily and a highly competent transport authority (i.e. TfL) with 27,000 employees and significant engineering resources. The TfL trial of hybrid-electric buses was carefully organised to test technologies as well as encourage competition. Four different vehicle makers participated in the trial, and six powertrains were tested; a number of bus operators were also involved. By announcing that London planned to have 1000 hybrid buses in regular operation by the 2012 London Olympics, TfL wanted manufacturers to build volume and reduce costs. At the end, around 300 hybrid buses were actually used on regular routes; this was still a significant number and it built the emerging hybrid bus market in Europe. Transport for London purchased 56 different hybrids to be used by various operators. This created highly visible competition among technologies as well as among manufacturers.

Today, with the announcement of our plans for hybrid buses in London, we are sending a clear message to London and the transport industry that we are serious about this. Transport for London will work with bus manufacturers and operators to 
take this important step, and they need to start working with us now. (Transport

Commissioner, London Government, 2006)

Volvo was the only European heavy vehicle manufacturer that participated in this contest, competing with American bus manufacturers and various suppliers of hybrid drive modules to British bus builders. In addition to monthly monitoring reports on reliability and efficiency, TfL organised surveys involving the end customers, i.e. the passengers. The analyses showed that some of the hybrid configurations had lower efficiency compared to the conventional diesel engines. Overall, however, the London tests substantiated the advantages of the hybrid-electric buses for urban purposes: significant reduction of fuel consumption (30\% or more), high reliability and robustness, and attractive features for the end customers (i.e. the passengers) such as low noise, reduced vibrations, and smooth ride (TfL, 2012a, 2012b).

\subsection{BAE Systems versus Volvo Buses}

The TfL strategy to invite and test several different solutions resulted in the emergence of two leading contenders: BAE Systems and Volvo Buses.

The defence conglomerate BAE Systems entered the US market for city buses in 1998 by delivering its HybriDrive to buses for New York City (Pfeifer, 2008). The Green Bus Fundprogram opened up the British market for BAE, and in 2010, the firm began to deliver its HybriDrive system to the bus builder Alexander Dennis. More orders followed, and in 2011, there were 100 buses with this drive on the streets of London (BAE, 2012, 2013). As a subsystem specialist, BAE Systems delivers its HybriDrive to both bus builders and integrated manufacturers (including Daimler in the US and Iveco Bus in Europe) which utilise BAE's HybriDrives instead of spending resources to develop their own hybrid systems. In some cases, BAE Systems procures all the major components (diesel engine, electric motor/generator, and energy storage) and delivers a complete powertrain to the bus builders. In other cases, the bus builders/vehicle manufactures procure BAE's hybrid management module and electrical components, but purchase the diesel engines separately. This approach creates flexibility in a period of uncertainty, where customers can avoid investments in technologies that may become obsolete; however, it is difficult to combine such an approach with overall powertrain optimisation.

Being a later entrant to the hybrid market than BAE Systems, Volvo started an aggressive international marketing campaign during the prototype stage itself. Early orders arrived from 
countries such as Luxembourg, Switzerland, Germany, and Denmark. However, participation in the London trial was the most important factor in Volvo's success. As explained by the Managing Director at Volvo Buses, UK:

The first time hybrids started going commercially for us I think everybody was very worried, /but..../we have to say that the experience three years later, so far /is very positive/... the fuel consumption saving is being delivered, and reliability ...really has been good. There is no doubt about that. (Managing Director, Volvo Buses, UK, interview in 2012)

In the trial, the Volvo buses came out on top, with high efficiency (37\% savings) and very high reliability despite 18-19 hours of daily service. As a result, Volvo's first British customer Arriva multiplied its orders to a total of 200 units in 2012, and started to employ hybrids outside London. Volvo supported this expansion with contracts for training drivers and long-term maintenance contracts based on its dense UK dealer network.

I would say they are as reliable, if not more reliable than some of the conventional diesel vehicles. They are brilliant, fantastic. (Interview with Arriva, 2012)

To further advance the development of the hybrid market, Volvo rapidly unveiled several technology initiatives. While launching its Euro 6-compatible engines in 2012, the company announced that hybrid powertrains would be the standard for all its future European city buses, a decision unmatched by any competitor. Subsequently, Volvo began field tests of plug-in versions with a more powerful battery in Gothenburg. They received an initial order for regular traffic in Stockholm in 2014 and other contracts with Edinburgh, Luxemburg and Hamburg. In inner-city applications, such plug-in hybrids have the potential to reduce diesel consumption by $80 \%$ and total energy use by $60 \%$, with the additional advantage of a smooth and silent ride.

\subsection{Problems of diffusion and economy of scale}

By 2012, BAE Systems had sold 3,500 series hybrid drives for bus applications in North America, Europe (the UK, France, and Spain), and Australia. The strategy of collaborating with bus builders for specific niche orders meant that economy of scale remained difficult to achieve despite the increasing volumes. To support its $R \& D$ efforts, the division relied on the group's major defence business, which offered hybrid-powered combat vehicles to the US Army (Szondy, 2012). 
Around the same time (2012), Volvo had delivered 1500 buses equipped with parallel hybrid systems in a substantially shorter period. Volvo had succeeded in moving out of the protected London city niche, receiving considerable commercial orders from the UK and Latin America. However, the bus market as a whole was still dominated by traditional diesel powertrains. Moreover, the company's platform strategy relied on the diffusion of the new powertrain in truck applications. However, the bus and truck markets differ significantly also in their urban applications. City buses operate on regular routes with garage service available daily, which reduces the risk of introducing new technology. For truck operators who deal with irregular routes and infrequent maintenance, thoroughly verified reliability is critical. While bus operators with public contracts may be satisfied with an economic payoff within six years, truck operators would require payoff within half that time. Local policymakers in the US and Europe have devised a range of instruments to encourage the use of new technologies in urban buses; however, this activity has not extended to the truck market (which is much more important in terms of volume). Thus, Volvo's truck division has been unable to find any market niches comparable to the city bus niche. After the delivery of 200 hybrid trucks to select customers, Volvo discontinued its production of hybrid trucks in 2013. A specialist at the company's advanced engineering unit reflected on the prospects for the market launch of trucks with hybrid and plug-in hybrid powertrains:

We have on-going studies about the requirements for electro mobility and briefly I can say that without policy instruments it will take quite some time until today's technology and the costs associated with it is commercially viable. It will take until about 2025 according to our simulations ... Therefore, now we are waiting. The strategy is clear and set - we have to go in this direction. But currently we are in a waiting mode and the interesting question is: does the society want to shorten the time lag? Are there any ambitions to make this happen about 2020? If so, policy incentives will be required. (Interview with Volvo Advanced Technology, 2014)

The delayed market introduction of hybrid truck applications meant that the company was far from achieving economies of scale by cost-efficient volume production. The cost problem was reflected in the overall evaluation at TfL, where satisfaction with the technical performance of the best hybrids was mixed with clear disappointment about their high cost. During the initial years of the trial, hybrids had commanded a $50 \%$ price premium compared to conventional diesel engines (300,000 pounds versus 200,000 pounds for a double-decker bus) and this premium had only come down very slowly. From their perspective, TfL had created the basis 
for volume, but from the manufacturers' point of view, '300 are small... maybe we need 3000; maybe we need 5000' (Managing director, Volvo UK, interview in 2012). Other decisions made in London illustrated the limitations of this type of niche for building economies of scale and the tendency to result in further fragmentation. In 2012, the agency awarded an order for 600 hybrid-powered 'New Bus for London' (a pet project of the new Mayor), not to any of the winners in the TfL trial but to an entirely new partnership, which soon reported significant cost increases (Topham, 2013). Instead of contributing to consolidation and cost reduction, TfL did the opposite. This demonstrates the problems manufacturers face when relying on the shifting priorities of local politics.

Despite these limitations, London constituted a very important technological niche for Volvo. The results from the field trials infused confidence in the technology within Volvo's own organisation and, thus, had a significant effect on the subsequent market launch decision. Moreover, bus operators could rely on TfL's independent evaluations of reliability and fuel consumption as vital inputs for their purchase decisions. Hence, the London field trials facilitated broader market expansion in the UK, which turned into the leading national market for hybrid buses in Europe.

\section{Case analysis and discussion}

\subsection{Two contrasting technology strategies}

Two contrasting technology strategies, illustrated by the parallel and series hybrid powertrains, emerge from our case studies of the development and commercialisation of hybrid-electric powertrains for heavy vehicle applications. Table 2 presents a brief comparison of these two strategies.

\section{(Insert Table 2 around here)}

A key aspect in the two technology strategies concerns the differences in architecture. The series hybrid powertrain with its modular architecture allows limited commitments and makes it possible for both large OEMs and smaller bus builders to separately offer/assemble hybrid vehicles for applications in dense stop-and-go city traffic. As noted by Cabral (2011: 540) 'since capacity costs are sunk while there is uncertainty regarding the technological path the 
industry will take, firms prefer to invest at small capacity levels even though a large capacity is more efficient'. In general, modular architectures offer less efficiency but greater flexibility and superior economies of scale (Christensen et al., 2002). In the industry studied here, the modular series hybrid enables customised production for narrow niches; however, it is associated with higher product costs, constrained scope, and fewer possibilities to build volume production. Therefore, Scania cancelled the development of this technology, whereas other OEMs in Europe continue to offer series hybrid systems developed by specialised suppliers when required by customers.

The parallel hybrid powertrain with its integral architecture requires significant investments in $R \& D$ and production equipment, but enables a broad range of applications in addition to stop-and-go city traffic. As demonstrated by Volvo, an intimate knowledge of the integral architecture and its technologies enables a process of technological deepening - from standalone hybrids to plug-in hybrids, and further, to full electrification based on a dedicated recharging infrastructure. Individual niche customers can be expected to cover only a small part of these investments. Thus, the technology not only enables but also requires broader diffusion. This imperative is embodied in Volvo's decision to make hybrid technology standard in its European city buses and to explore the possibility of acceptance for the new technology in truck applications. However, in the absence of supporting niches beyond the city bus segment, this diffusion has remained elusive.

As shown in the above discussion, different market strategies align with the two technology strategies. Taken together, these technology and market strategies can be seen as two contrasting strategies of separation versus integration. While the separation strategy (illustrated by the series hybrid technology) focuses on narrow market niches unconnected to the industry's main markets, the integration strategy (illustrated by the parallel hybrid powertrain) is designed for applications across several different market segments.

\subsection{Technology strategies and transition pathways}

Hybrid-electric powertrains represent an important stepping-stone in a broader transition from the current road transport regime built on vehicles propelled by internal-combustion engines to a future regime based on electric propulsion (Geels, 2005; Sandén and Hillman, 2011). Hybrid-electric powertrains, however, can be developed and embedded in highly different 
strategies of firms, with vastly different implications for niche-regime interactions and transition pathways towards heavy vehicle electrification.

Referring to the pathway typology presented by Geels and Schot (2007), the separation strategy built around a modular architecture adopted for a specific market niche could be seen as a variant of reconfiguration. The incumbent regime actors adopt component innovations developed by the new suppliers; however, they continue to devote a majority of their resources to the further development of their established core technologies in a state of co-existence of 'transitional' technologies at the niche level and established technologies at the regime (major market) level. In the empirical studies discussed earlier, Scania represents such a case. BAE Systems, on the other hand, represents a subsystem specialist from an established actor in another regime, who entered the urban bus market as a niche supplier, linking up with smallscale bus builders and heavy vehicle manufacturers. By outsourcing, OEMs following this separation strategy will be able to reduce their internal R\&D investments; however, they will lose out on opportunities to build architectural knowledge and integrative capabilities (Becker and Zirpoli, 2003). Moreover, the high product cost and lack of synergies associated with this configuration suggest that this technological configuration will be difficult to justify on a broader commercial basis. As the potential synergies between the niche-level activities and the incumbents' main business are limited, a positive niche-regime interaction will hardly emerge. Under such circumstances, sales will continue to depend on the existence of politically induced proto-markets or niches (Kemp et al., 1998; Smith and Raven, 2012).

In contrast, the integration strategy built around the parallel hybrid architecture presents the potential for a more elaborate niche-regime interaction and a broader transition to electrified heavy vehicles. The key actor studied in this context invested in the development of new as well as existing component technologies and integrated them in new architectural solutions, combining internal $R \& D$ efforts with external sources of technology from outside the industry. New suppliers played important roles in this case. However, the need for systemic integration across engineering disciplines and product applications resulted in a more comprehensive innovation strategy than the one implied by a reconfiguration pathway. The envisioned pattern of step-wise market diffusion, in which the technology gradually enters larger market segments, is similar to a technological substitution pathway (Geels and Schot, 2007). However, a crucial difference is that a regime actor drives the substitution in the studied context. This can be seen as an example of creative accumulation (Bergek et al., 2013), where the incumbents' existing knowledge forms the basis for expanding their available choices 
instead of serving as a source of inertia (cf. King and Tucci, 2002). Niche actors may be important to signal the new technological opportunities; however, in an industry such as heavy vehicles new entrants face insurmountable obstacles in mastering the complex knowledge required to develop competitive products that can satisfy the markets' range of performance requirements, including efficiency, convenience, functionality, robustness, reliability, safety, and cost. Thus, the industry incumbents remain key actors in this type of capital goods industries. The new technology options reinvigorate the competition, however, and present the incumbents with significant challenges (Bergek et al., 2013); moreover, the strategic choices are by no means straightforward. The case studies demonstrate the power of an integrated strategy in terms of technological deepening and potential market appeal; they also show that such a strategy entails risky investments in a period of high and prolonged uncertainty.

\subsection{Established firms in the multi-level framework}

The initiatives, decisions, and actions of actors are necessary for realising sustainability transitions. The multi-level framework, however, typically gives very limited attention to the role of individual actors, and in a simplistic way positions established firms only at the regime level and newcomers at the niche-level (Geels and Schot, 2007). The studies presented in this paper, however, show that industry incumbents act both at the regime and at the niche levels, and may drive further niche development, competing with other industry incumbents as well as new entrants. In fact, taking positions in niches while retaining their activities at a regime level seem to be the likely responses to the emerging opportunities for industry incumbents both in the focal regime and in adjacent regimes. The subsystem specialist in the second study (BAE Systems), an incumbent regime-level actor in the defence industry, illustrates the latter phenomenon. Hence, the classification of actors according to one particular position in the multi-level framework - as either regime-level or niche-level actors - is very static. There is a need for more dynamic representations of actors' behaviours in transition processes. Moreover, because of the long periods of uncertainty involved, the levels at which an actor operates are likely to change over time. This observation finds support in Jørgensen (2012: 1008), who claims that 'actors engage in all levels of society' in their attempts to navigate their way through transitions. In turn, this implies that the strategies and actions of individual firms determine important niche-regime interactions. 
Researchers adopting the multi-level perspective on sustainability transitions emphasise the importance of niches in building social acceptance for new technologies (Kemp et al., 1998); they stress that students and actors need to understand political processes and analyse 'the diverse (political) narratives seeking to empower niches across time and space' (Smith and Raven, 2012: 1025). The case analyses presented in this paper confirm the importance of politically supported niches for the market introduction of capital-intensive complex products. However, the paper also demonstrates the limits of such niches, their susceptibility to contradictory agendas and fragmentation, and the difficulty for niche actors to expand and enter adjacent market segments, which is necessary to create the economies of scale needed to achieve competitive costs. For small-scale producers or newcomers relying on the effects of economy of scope from other businesses, this may be a secondary problem. For a broader transition, however, niches are only one building block, as noted in a recent study of the obstacles encountered by electric vehicles (Steinhilber et al., 2013).

Therefore, niche-regime translations are required. Discussing such translations, Smith (2007: 446) argues that 'performance criteria in niche and regime need to come into some kind of correspondence - translating what works in the niche into something that also works in the regime'. While Smith (2007) outlines different forms of translation, our analysis highlights the role of actors and strategies in these translations. In particular, it emphasises the importance of firms that operate as multi-level actors and adopt technology strategies that enable market expansion beyond the original narrow niches to reach a point where the new technology is attractive in more cost-sensitive segments as well. Further, the studied cases illustrate that firm strategies depend on the emergence of bridging policies (Sushandoyo and Magnusson, 2014), for broadening as well as deepening; i.e. to link early niches to broader markets and to support the development of transitional markets for more advanced levels of technology.

\section{Conclusion}

Scholars adopting the multi-level perspective have argued that interactions and translations between niches and regimes are critical for understanding sustainability transitions. They have also outlined different transition pathways involving different sets of actors. However, prior attempts to incorporate actors in the multi-level framework suffer from a tendency to outline stereotypical conceptualisations, resulting in the risk of static representations of the behaviours of actors. The analysis presented in this paper contributes to the understanding of transition pathways by providing a differentiated analysis of the strategies of established firms - how 
they may complement an existing regime with a limited transitional technology or contribute to a potentially broad transition from the existing regime. The analysis challenges the perception of 'regime actors' as conservative forces who resist change if not forced to embrace it by the dynamism of new niches, and shows that regime actors may drive radical innovation at the niche level as well. This calls for a more fine-grained analysis of transition pathways and a more dynamic positioning of actors in the multi-level framework. Moreover, it calls for an analytical approach that transcends the regime-niche dichotomy and embraces studies of the interactions between firm strategies and bridging policies, based on an understanding of the dependence of transitions on economies of scale beyond niches and niche strategies. 


\section{References}

Abernathy, William J. 1978. The Productivity Dilemma: Roadblock to Innovation in the Automobile Industry. Baltimore: John Hopkins University Press.

Anderson, Ph., Tushman, M.L. 1990. Technological Discontinuities and Dominant

Designs: A Cyclical Model of Technological Change, Administrative Science Quarterly 35, 4, 604-635.

Andersson, B.A., Jacobsson, S., 2000. Monitoring and assessing technology choice: the case of solar cells. Energy Policy 28, 1037-1049.

Arthur, W.B., 1989. Competing Technologies, Increasing Returns, and Lock-In by Historical Events. The Economic Journal 99, 116-131.

BAE 2012. BAE makes big bet on hybrid-electric drive, National Defense Business and Technology Magazine. Oct 23.

BAE 2013. http://www.hybridrive.com/history.asp, accessed on 13 February.

Becker, M.C. and Zirpoli, F. 2003. Organizing new product development: Knowledge hollowing-out and knowledge integration - the FIAT Auto case, International Journal of Operation \& Production Management, 23(9), 1033-1061.

Bergek, A., Berggren C., Magnusson T., and Hobday M. 2013. Creative accumulation and disruptive innovation: contrasting cases of technology-induced industrial change, Research Policy, 42, 1210-1224.

Bergek, A., Berggren, C., Magnusson, T. 2011. Creative Accumulation: Integrating New and Established Technologies in Periods of Discontinuous Change, in Berggren, C., A. Bergek, L. Bengtsson, M. Hobday, and J. Söderlund (Eds.). 2011. Knowledge Integration \& Innovation Critical Challenges Facing International Technology-based Firms. Oxford: Oxford University Press.

Bergek, A., Berggren, C., Tell, F. 2009. Do technology strategies matter? A comparison of two electrical engineering corporations, 1988 - 1998, Technology Analysis and Strategic Management, 21, 4, 445-470. 
Berggren, C. 2004. Global dreams - local teams. International Journal of Innovation Management. 8, 3, 115-145.

Brusoni, S., Prencipe, A., and Pavitt, K., 2001.Knowledge Specialization, Organizational Coupling and the Boundaries of the Firm: Why Do Firms Know More than They Make? Administrative Science Quarterly, 46, 597-621.

Cabral, L. 2011. Technology uncertainty, sunk costs and industry shakeout, Industrial and Corporate Change, 21, 3, $539-552$.

Christensen, C.M., Verlinden, M. and Westerman, G. 2002. Disruption, disintegration and the dissipation of differentiability, Industrial and Corporate Change, 11, 5, 955-993.

Christensen, Clayton M. 1997. The Innovator's Dilemma. When New Technologies Cause Great Firms to Fail. Boston, MA: Harvard Business School Press.

Collins, P.D., F.M. Hull, and J. Hage. 1996. Profiles of leaders, followers, and laggards in programmable automation adoption. IEEE Transactions on EM 43, no. 3: 285-296.

Cowan, R., 1990. Nuclear Power Reactors: A Study in Technological Lock-in. The Journal of Economic History 50, 541-567.

Cowan, R., Gunby, P., 1996. Sprayed to Death: Path Dependence, Lock-in and Pest Control Strategies. The Economic Journal 106, 521-542.

De Liso, N., Filatrella, G., 2008. On technology competition: a formal analysis of the 'sailingship effect'. Economics of Innovation and New Technology 17, 593-610.

de Vries, de Ruijter, J., Argam, N. 2011. Dominant design or multiple designs: the flash memory card case. Technology Analysis \& Strategic Management, 23:3, 249-262

Dijk, M. and Yarime, M. 2010. The emergence of hybrid-electric cars: Innovation path creation through co-evolution of supply and demand Technological Forecasting and Social Change, 77, 8, 1371-1390.

Eriksson, S., 2007. Electrical Machine Development: a study of four different machine types from a Swedish perspective. Dissertation. Stockholm: Royal Institute of Technology. existing product technologies and the failure of established firms, Administrative Science Quarterly, 35(1), 9-30. 
FCHJU, The Fuel Cells and Hydrogen Joint Undertaking. 2012. Urban buses: alternative powertrains for Europe, McKinsey, Nov 2012.

Folkesson, A. 2008. Toward sustainable urban transportation: Test, demonstration and development of fuel cell and hybrid-electric buses. Dissertation, Stockholm: Royal Institute of Technology.

Fuenfschilling, L. and Truffer, B. 2014. The structuration of socio-technical regimesConceptual foundations from institutional theory Research Policy 43, 4, 772-791

Geels, F.W., 2002. Technological transitions as evolutionary reconfiguration processes: a multi-level perspective and a case-study. Research Policy 31, 1257-1274.

Geels, F.W., 2004. From sectoral systems of innovation to socio-technical systems: Insights about dynamics and change from sociology and institutional theory, Research Policy 33, 6-7, $897-920$

Geels, F.W., 2005. Processes and patterns in transitions and system innovations: refining the co-evolutionary multi-level perspective. Technological Forecasting and Social Change 72, 681.

Geels, F.W., Kemp, R., 2007. Dynamics in socio-technical systems: Typology of change processes and contrasting case studies, Technology in Society, 29, 4, 441-455

Geels, F.W., Schot, J., 2007. Typology of sociotechnical transition pathways. Research Policy $36,399-417$.

Gerring, J. 2008. Case selection for case-study analysis: qualitative and quantitative techniques, in Box-Steffensmeier, J. (ed.) Oxford Handbook of Political Methodology, 645684. OUP.

Guzella, L., Sciarretta, A. 2005. Vehicle Propulsion Systems: Introduction to Modeling and Optimization, Second Edition. Springer, Berlin, Heidelberg, New York.

Helfat, C. E. and R. Raubitschek, 2000. Product sequencing: co-evolution of knowledge, capabilities and products, Strategic Management Journal, 21, 961-979.

Henderson, R. M. and K. B. Clark. 1990. Architectural innovation: the reconfiguration of Hoogma, R., Kemp, R., Schot, J. and Truffer, B., 2002. Experimenting for Sustainable Transport. The approach of Strategic Niche Management, Spon Press, London. 
Iansiti M., 1995. Technology integration: Managing technological evolution in a complex environment, Research Policy, 24, 521-542.

Jørgensen, U. 2012. Mapping and navigating transitions - The multi-level perspective compared with arenas of development, Research Policy, 41, 6, 996-1010

Kemp, R., Schot, J., Hoogma, R. 1998. Regime Shift to Sustainability through Process of Niche Formation: the Approach of Strategic Niche Management, Technology Analysis \& Strategic Management, 10(2), p. 175-195.

KPMG, 2011. Competing in the global truck industry, accessed on 24 June 2013.

Lee, J., Veloso, F.M., Hounshell, D.A., and Rubin, E.S. 2010. Forcing technological change: a case of automobile emissions control technology development in the US, Technovation, 30, 249-264.

Lee, Ji-Ren, O'Neal, D. , Pruett, M., Thomas, H. 1995. Planning for dominance: a strategic perspective on the emergence of a dominant design, R\&D Management, 25, 1, 3-25.

London Gov. (2006) http://www.london.gov.uk/media/mayor-press-releases/2006/10/ mayorlaunches-plan-for-london-hybrid-bus-fleet, accessed on 16 April 2013.

Lowe, M., Aytekin, B. and Gereffi, G. 2009. Manufacturing Climate Solutions, Ch 12 Public Transit Buses. Center on Globalization Governance and Competitiveness, Duke University.

Magnusson, T. and Berggren, C. 2011. Entering an era of ferment - radical vs. incrementalist strategies in automotive power train development. Technology Analysis and Strategic Management, 23, 3, 313-330.

Maidique, M.A., and P. Patch. 1982. Corporate strategy and technological policy. In: Readings in the management of innovation, ed. M.L. Tushman and W.A. Moore. Marchfield: Pittman.

Markard, J., Raven, R., Truffer, B. 2012. Sustainability transitions: An emerging field of research and its prospects, Research Policy 41, 6, 955-967

Menanteau, P., Lefebvre, H., 2000. Competing technologies and the diffusion of innovations: the emergence of energy-efficient lamps in the residential sector. Research Policy 29, 375389. 
Mikkola, J.H. 2003. Modularity, component outsourcing and inter-firm learning. R\&D Management, 33, 4, 439-454.

Moore, G. 1991/1999. Crossing the Chasm. Harper Business Essentials. New York, N. Y. O’Reilly, C.A.I., Tushman, M.L., 2004. The ambidextrous organization. Harvard Business Review 82, 74-81.

Offer, G.J., Howey, D., Contestabile, M, Clague, R., Brandon, N.P. 2010.

Olleros, F. J. 1986. Emerging industries and the burnout of pioneers, Journal of Product Innovation Management, 1, 5-18.

Overgaard, L., Folkesson, A., 2007. Scania hybrid concept - with robust technology into the future, $57^{\text {th }}$ UITP World Congress.

Pavitt, K., 1986. 'Chips' and 'Trajectories': How Does the Semiconductor Influence the Sources and Directions of Technical Change?, in: MacLeod, R. (Ed.), Technology and the Human Prospect. Frances Pinter, London, pp. 31-54.

Pfeifer, S. 2008, BAE joins queue for London bus. Financial Times, November 18.

Rip, A., 1995. Introduction of new technology: Making use of recent insights from sociology and economics of technology. Technology Analysis \& Strategic Management 7, 417-431.

Sandén, B. A., Hillman, K. M., 2011. A framework for analysis of multi-mode interaction among technologies with examples from the history of alternative transport fuels in Sweden. Research Policy 40, 403-414.

Scania 2004. PD-Guiden 200414. Vägvisaren för Scanias produktutveckling, Scania.

Scania 2007. Annual Report.

Scania 2011. Annual Report.

Schot, J. and Geels, F.W. 2008. Strategic niche management and sustainable innovation journeys: theory, findings, research agenda, and policy, Technology Analysis \& Strategic Management, 20 (5), 537-554.

Schot, J., Hoogma, R. Elzen, B. 1994. Strategies for shifting technological systems: the case fo the automobile system, Futures 26, 10, 1060-1076

Schumpeter, J. 1911/2008., Theory of Economic Development. New Brunswick: Transaction Publishers. 
Schumpeter, J. 1942/2010. Capitalism, Socialism and Democracy. London and New York: Routledge.

Sierzchula,W., Bakker, S., Maat, K., van Wee, B. 2012. Technological diversity of emerging eco-innovations: a case study of the automobile industry, Journal of Cleaner Production, 37 , $211-220$.

Smith, A. 2007. Translating Sustainabilities between Green Niches and Socio-Technical Regimes, Technology Analysis \& Strategic Management, 19, 4, 427-450

Smith, A. and Raven, R. 2012. What is protective space? Reconsidering niches in transitions to sustainability, Research Policy, 41, 1025-1036.

Smith, A., Stirling, A., Berkhout, F., 2005. The governance of sustainable sociotechnical transitions. Research Policy 34, 1491-1510.

Smith, A., Voss, J-P., Griin, J. 2010. Innovation studies and sustainability transitions: The allure of the multi-level perspective and its challenges, Research Policy 39, 4, 435-448

Sölvell, Ö., Zander, I., Porter, M. 1999. Advantage Sweden. Palgrave Macmillan.

Steinhilber' S., Wells'P., Thankappan, S. 2013. Socio-technical inertia: Understanding the barriers to electric vehicles. Energy Policy 60, 531-539.

Suarez, F.F. 2004. Battles for technological dominance: an integrative framework. Research Policy 33, no. 2: 271-286.

Sushandoyo, D. and Magnusson, T. 2014. Strategic niche management from a business perspective: taking cleaner vehicle technologies from prototype to series production, Journal of Cleaner Production, In Press

Szondy, D. 2012. BAE Systems releases details of hybrid tank, Gizmag, November 22. Takeishi, A. 2002. Knowledge partitioning in the interfirm division of labor: the case of automotive product development, Organization Science, 13, 3, 321-338.

TfL 2009. Hybrid Bus Customer Evaluation. London: Transport for London.

TfL 2012a. Interview Helen Wolston, environmental coordinator, April 27.

TfL 2012b. Interview Mike Weston, chief engineer, June 15.

TfL 2013. Hybrid buses, http://www.tfl.gov.uk/corporate/projectsandschemes/2019.aspx, accessed on 13 February 2013. 
Topham, G. 2013. Hop on for Pamlico: Boris bus takes to first London Route, Guardian, June 20, p 17.

Veryzer, R.W. 1998. Discontinuous innovation and the new product development process, Journal of Product Innovation Management, 15, 304-321.

Vidal, E. and Mitchell, W. 2013. When Do First Entrants Become First Survivors? Long Range Planning, Available online 19 July.

Volvo, 2007. www.volvo.com/NR/rdonlyres/33DB791Dy/Volvo_Hybrid_Report.pdfS, accessed on 20 June 2010

Volvo, 2012. http://www.volvobuses.com/bus/france/fr-

fr/_layouts/CWP.Internet.VolvoCom/NewsItem.aspx?News.ItemId=130633\&News.Language =en-gb, accessed on 24 June 2013.

Well, P. and Nieuwenhuis, P. 2012. Transition failure: Understanding continuity in the automotive industry, Technological Forecasting \& Social Change 79, 1681-1692. Wesseling, J.H., Faber,J. and Hekkert, M.P. 2013. How competitive forces sustain electric vehicle development, Technological Forecasting and Social Change, In Press, Available online 8 March.

Wheelwright, S.C., and Clark, K.B. 1992. Creating product plans to focus product development, Harvard Business Review, 70, 2, 67-83.

Zahra, S.A., Nash,S. and Bickford, D.J. 1994. Creating a competitive advantage from technological pioneering, IEEE Engineering Management Review Spring: 76-85.

Zahra, S.A., Sisodia, R., and Matherne, B. 1999. Exploiting the dynamic links between competitive and technology strategy, European Management Journal 17, 2, 188-203.

Zirpoli F. and Becker M.C. 2011. The limits of design and engineering outsourcing: performance integration and the unfulfilled promises of modularity, R\&D Management, 41 , 21-43. 


\section{Appendix A: A list of interviewees}

\section{Interviews with Volvo}

\begin{tabular}{|l|l|l|}
\hline Interviewee & Organisation & Year \\
\hline Environmental Director & Volvo Bus, HQ & 2012,2013 \\
\hline Managing Director & Volvo Bus UK & 2012 \\
\hline $\begin{array}{l}\text { Product Engineering } \\
\text { Manager }\end{array}$ & Volvo Bus UK & 2012 \\
\hline Director & $\begin{array}{l}\text { Volvo Advanced Technology } \\
\text { \& Research }\end{array}$ & 2012 \\
\hline Manager & $\begin{array}{l}\text { Business Package Team/ } \\
\text { Volvo Advanced Technology } \\
\text { \& Research }\end{array}$ & 2009,2012 \\
\hline Scientific Advisor & $\begin{array}{l}\text { Volvo Advanced Technology } \\
\text { \& Research }\end{array}$ & 2008,2012 \\
\hline $\begin{array}{l}\text { Energy storage } \\
\text { (battery) engineer }\end{array}$ & Volvo Technology & 2009 \\
\hline $\begin{array}{l}\text { Project Manager } \\
\text { Hybrid Development }\end{array}$ & Volvo Powertrain & 2007 \\
\hline Environmental manager & Volvo 3P & 2013 \\
\hline $\begin{array}{l}\text { Director Product Platform } \\
\text { Electromobility }\end{array}$ & $\begin{array}{l}\text { Volvo Group Trucks } \\
\text { Technology }\end{array}$ & 2014 \\
\hline $\begin{array}{l}\text { Transport Solution } \\
\text { Specialist }\end{array}$ & $\begin{array}{l}\text { Volvo Advanced Technology } \\
\text { \& Research }\end{array}$ & 2014 \\
\hline CEO (1997-2011) & Volvo Group & 2014 \\
\hline
\end{tabular}

Interviews with Scania and its main partners

\begin{tabular}{|ll|l|}
\hline Interviewee & Organisation & Year \\
\hline Head/ Vice president & R\&D department & 2009,2013 \\
\hline Head/ Vice president & R\&D department & 2013 \\
\hline Director & Vehicle Definition division & 2008 \\
\hline Engineering Director & Bus Chassis Development & 2008 \\
\hline Manager & $\begin{array}{l}\text { Parallel Hybrid Development } \\
\text { Group }\end{array}$ & 2008,2011 \\
\hline $\begin{array}{ll}\text { Project manager/ } \\
\text { leader }\end{array}$ & $\begin{array}{l}\text { Series hybrid electric bus } \\
\text { prototype project }\end{array}$ & 2009 \\
\hline $\begin{array}{l}\text { Project manager/ } \\
\text { leader }\end{array}$ & $\begin{array}{l}\text { Series hybrid electric bus } \\
\text { prototype project }\end{array}$ & 2008,2011 \\
\hline Manager & Hybrid components group & 2008 \\
\hline Engineer & Bus chassis development & 2008 \\
\hline $\begin{array}{l}\text { Energy storage } \\
\text { (battery) engineer }\end{array}$ & R\&D Department & 2009 \\
\hline
\end{tabular}




\begin{tabular}{|l|l|l|}
\hline $\begin{array}{l}\text { Control } \\
\text { engineer }\end{array}$ & R\&D Department & 2010 \\
\hline $\begin{array}{l}\text { Project/ Technical } \\
\text { leader }\end{array}$ & Voith Turbo, Germany & 2010 \\
\hline
\end{tabular}

Interviews with BAE Systems, in 2012.

\begin{tabular}{|l|l|}
\hline Interviewee & Organisation \\
\hline Project Manager & BAE Systems \\
\hline Technology Manager & Alexander-Dennis \\
\hline
\end{tabular}

Interviews with customers and Transport for London, in 2012.

\begin{tabular}{|l|l|}
\hline Interviewee & Organisation \\
\hline Engineering Director & Arriva-London \\
\hline $\begin{array}{l}\text { Group Technical } \\
\text { Engineer }\end{array}$ & Stagecoach, London \\
\hline Engineering Director & Go Ahead, London \\
\hline $\begin{array}{l}\text { Business } \\
\text { Improvement Director }\end{array}$ & First Group, London \\
\hline Operations Director & GS Bus, London \\
\hline Fleet Manager & Nobina-Stockholm \\
\hline $\begin{array}{l}\text { Fleet/ Operations } \\
\text { Director }\end{array}$ & Ragn-Sells, Stockholm \\
\hline $\begin{array}{l}\text { Vehicle Development } \\
\text { Manager }\end{array}$ & Renova, Gothenburg \\
\hline $\begin{array}{l}\text { Bus Operations } \\
\text { Directors }\end{array}$ & Transport for London \\
\hline $\begin{array}{l}\text { Environmental and } \\
\text { Climate Change }\end{array}$ & Transport for London \\
\hline
\end{tabular}


Table 1. Two set of case studies

\section{Study 1.}

Focus of study Technology strategies: selection, scope, organization, knowledge sourcing (internally and externally).

Studied firms $\quad$ Two Swedish industry incumbents (OEMs): Scania and Volvo

Period $2005-2010$.

\section{Study 2.}

Focus of study Market strategies and early commercialization in the UK, technical performance, sales and further challenges.

Studied firms Volvo Bus, the successful candidate in study 1, compared with BAE Systems, a new hybrid system supplier on the UK market

Period $2010-2012$

Table 2 Strategy comparison - heavy vehicle powertrains

\section{Parallel hybrid $\quad$ Series hybrid}

\begin{tabular}{lll} 
Architecture & Integral & Modular \\
Scope & Product platform & Specific product \\
R\&D investment at OEM & High & \multicolumn{1}{c}{ Limited } \\
Knowledge sourcing & $\begin{array}{l}\text { Significant in-house } \\
\text { development plus } \\
\text { supplier collaboration }\end{array}$ & $\begin{array}{l}\text { Significant outsourcing } \\
\text { (vertical disintegration) }\end{array}$ \\
Product cost & $\begin{array}{l}\text { Higher than existing } \\
\text { products, lower than } \\
\text { series hybrid }\end{array}$ & High \\
& $\begin{array}{l}\text { Energy savings in all } \\
\text { applications, best in } \\
\text { stop/go }\end{array}$ & $\begin{array}{l}\text { Only savings in stop/go mode; } \\
\text { inferior to conventional }\end{array}$ \\
vechnical performance & $\begin{array}{l}\text { Potentially all urban/ } \\
\text { semi-urban segments }\end{array}$ & $\begin{array}{l}\text { Inner-city vehicles with } \\
\text { high frequency of stop/go }\end{array}$
\end{tabular}

